UDK 782.9 Žebre

\title{
SCENSKA GLASBA DEMETRIJA ŽEBRETA
}

\section{Milena $\check{Z}$ i d a n i k (Nova Gorica)}

Skladateljsko ustvarjanje Demetrija Žebreta je bilo povezano tudi z gledališkim delovanjem. V letih 1940-1953 so uprizorili v Drami Slovenskega narodnega gledališča $\mathrm{v}$ Ljubljani sedem dramskih del $\mathrm{z}$ njegovo scensko glasbo. 21. septembra 1940 so s premiero Romea in Julije Williama Shakespeara odprli sezono $1940 / 41 .^{1}$ 27. septembra $1941^{2}$ je bila predstava Katarine Medičejske Rina Alessija. ${ }^{3}$ Še isto sezono $1941 / 2$ (premiera 5. oktobra 1941) so igrali na ljubljanskem odru Shakespearovega Hamleta. ${ }^{4}$ Premiera Kavarnice Carla Goldonija, ${ }^{5}$ za katero je Žebre napisal glasbene točke, je bila 29. oktobra $1943 .{ }^{6}$ Tudi v Kranjskih komedijantih Bratka $\mathrm{Krefta}^{7}$ je »muziko zložil Žebrè«. ${ }^{8}$ Odrska uprizoritev je bila 21. oktobra 1948.9 Shakespearovega Kralja Leara so z Žebretovo scensko glasbo prvikrat igrali 4 . novembra $1949 .{ }^{10} \mathrm{Krstna}$ predstava drame Ćlovek je dober Josipa Kulundžića, ${ }^{11}$ 17. junija 1953, je bila opremljena z glasbenimi motivi F. Chopina in D. Žebreta. ${ }^{12}$

Ohranjeno je rokopisno notno gradivo k štirim dramskim delom. V skladateljevi zapuščini najdemo scensko glasbo k Romeu in Juliji, Katarini Medičejski, Hamletu in Krajnskim komedijantom. Kdaj je glasba nastajala, je zapisano na gradivu: za Romea in Julijo 16. septembra 1940, za Katarino Medičejsko 23. septembra 1941 in za Hamleta 24. septembra 1941. Glasba h Krajnskim komedijantom nosi dve datumski oznaki, 7. marec 1941 in 19. marec 1941, zato lahko sklepamo na začetek in konec komponiranja. Nastajanje Žebretove scenske

1. GL (Gledališki list) SNG Ljubljana, Drama, 1940-41, št. 1.

2 GL SNG Ljubljana, Drama, 1941-42, št. 1.

3 Hrvatska enciklopedija I, Zagreb 1941, str. 219; Il Piccolo, 3. VII. 1970, 4.

4 GL SNG Ljubljana, Drama, 1941-42, št. 2.

5 ELZ (Enciklopedija leksikografskog zavoda) II, 1967, 566.

- GL SNG Ljubljana, Drama, 1943-44, št. 4.

7 Gl. Slovenska književnost 1945-1965, II, Ljubljana 1967, 401.

- GL SNG Ljubljana, Drama, 1956-57, št. 7.

- GL SNG Ljubljana, Drama, 1948-49, št. 2.

10 GL SNG Ljubljana, Drama, 1949-50, št. 2.

11 ELZ III, $1967,694$.

12 GL SNG Ljubljana, Drama, 1952-53, št. 10. 
glasbe in uprizoritev dramskega dela sta si pri vseh delih časovno zelo blizu. Le Krajnski komedijanti so doživeli krstno predstavo šele 21 . okobra $1948 .^{13}$

Pojem scenske glasbe v širšem smislu vključuje vsako glasbo, ki je povezana $\mathbf{s}$ scenskim dogajanjem. Že stara ljudstva so poznala povezanost glasbe $\mathrm{z}$ besedo in gibanjem. Tudi antična grška tragedija je bila deloma izvajana z glasbo. V ožjem smislu pa ta izraz označuje glasbo, ki je najpogosteje instrumentalna, in na odrskem prizorišču, za njim ali v prostoru za orkester spremlja dogajanje na sceni. ${ }^{14}$

Osip Šest v razpravljanjih o Shakespearu in muziki med drugim razčlenjuje vrstnost scenske glasbe. Tako pravi: »Pojem igrokazne muzike obsega v svojem širšem smislu tri različne vrste $k$ igri spadajoče muzike. Prva je muzika, ki je v najožjem pomenu besede povezana $z$ odrom in bi ji zato lahko rekli tudi odrska muzika. To je muzika, ki jo pisatelj - dramatik sam zahteva in je torej nerazdružna $z$ dejanjem in potekom igre. To srečamo najprej, če morajo nastopajoče osebe govor spremeniti v petje, in sicer kot posamezniki ali v skupinah. $V$ teh primerih se vlože solo-točke ali pa zbori. K tej zvrsti sodijo tudi vse od dejanja terjane fanfare, muzikalni signali, koračnice, instrumentalne spremljave pri pojedinah, plesne scene in podobne prigode, nadalje muzika pri cerkvenih ceremonijah in pogrebih, pa še pri scenah v naravi.

Druga vrsta igrokazne muzike bi bila ona, ki jo smemo označiti za táko v pravem smislu besede. To je muzika, s katero postavi komponist svoje glasbeno delo samostojno v službo pisatelja in skuša z muzikalnimi sredstvi označiti dejanje in poglobiti povezavo med posameznimi dejanji. $\mathrm{K}$ tej zvrsti spada veliki ohranjeni zaklad igrokaznih uvertur...

Tretjo zvrst bi lahko imenovali tisto muziko $v$ drami, ki jo uporabljajo kot uvodno ali povezujočo dejanja ali zaključujočo igro. Ta navadno nima nikakršne

13 Dva članka pojasnjujeta nastanek in tako pozno uprizoritev Krajnskih komedijantov. Avtor sam v razgovoru navaja: „Ne bi mogel reči, da je bilo obdobje mojega življenja, v katerem sem pisal 'Komedijante', kdo ve kako srečno, mirno in prijetno, saj sem jih napisal v letih 1939-40, ko se je začela druga svetovna vojna in ko tudi razmere v stari Jugoslaviji niso bile zame nič kaj rožnate... Krstno predstavo 'Krajnskih komedijantov', za katero je bil v tiskarni že postavljen letak - en odtis hranim - je najprej preprečila vojna. ( $I z$ razgovora $z d r$. Bratkom Kreftom, GLSNG v Ljubljani, Drama, 1956-57, št. 7, 2১3.) Dušan Moravec pa je zapisal: »Komedija je bila rojena tako rekoč na predvečer velikega svetovnega spopada in to ji je določilo kaj neprijazno usodo. Narodno gledališče v Ljubljani jo je sicer sprejelo v svoj repertoar in Slovenska matica v knjižni program, vendar - knjiga je morala čakati celih pet let, gledališče pa celo sedem. Vaje so takrat sicer že tekle in ko bi se zavlekel začetek vojne lé še za nekaj dni, bi bila premiera, saj se je ohranil celo odtis že potavljenega letaka. ...Takoj po okupaciji je gledališko vodstvo vaje sicer obnovilo, toda komedija je - kot je ob poznejšem krstu zapisal avtor - doživela to čast, da je bila prvo slovensko delo, katerega uprizoritev je okupator prepovedal. Podobno je bilo tudi v tiskarni. ... Vendar, ko so se vremena zjasnila, je Slovenska matica poslala besedilo Krajnskih komedijantov v svet kot eno svojih prvih publikacij, Drama SNG pa jih je nekaj zatem uprizorila. Vendar tudi še takrat, po tolikih letih, Komedijanti niso mogli brez vseh zapletov na oder: malo je manjkalo. da bi črtali avtorju lik škofa Brigide, ene značilnih postav takratnega ljubljanskega življenja.« Dalje pravi, da je priprave za premiero 21. oktobra 1948 »vodil avtor sam - na letaku je bilo zapisano, tako kakor še pri nekaterih poznejših uprizoritvah - da - »reshijo pelá Dr. Kreft, pomaga mu pak prof. Mahnizh». ...Scena je bila delo ing. arh. Franza, glasbo pa je napisal Demetrii Žebre.« (Moravec D., Pota Krajnskih komedijantov, GL MGL, 1966-67 št. 7.)

14 Prim. Scenska muzika, ME III, 1977, 282-283; Scenska muzika, ELZ V, 1969, 651. 
notranje zveze z dejanjem. Maši samo 'luknje’ in se poslužuje vsega - od šlagerja do Becthovnove simfonije. ${ }^{15}$

Tako skuša naloga tudi na podlagi Šestove razvrstitve razkriti značilnost Žebretove scenske glasbe. Predmet obdelave je glasba k dvema dramskima deloma. Upoštevani so torej Kreftovi Krajnski komedijanti ter Romeo in Julija W. Shakespeara. Da se je izbor omejil ravno na obdelavo teh dveh del, je možno obrażložiti. Ohranjenega je največ notnega gradiva, ki vsebuje tudi instrumentalne parte. Razen tega sta bili deli največkrat izvajani. Krajnske komedijante še danes uprizarjajo z Žebretovo scensko glasbo. Analiza glasbe h Katarini Medičejski in Hamletu je šamo okvirna. ${ }^{16}$

Leta 1967 je Dušan Moravec v spremni besedi h Kreftovim Krajnskim komedijantom zapisal: »Krajnski komedijanti so bleščeča komedija $v$ najčistejšem pomenu te besede, pisateljevo najvedre ǰse in najtoplejše delo in hkrati eno najbolj žlahtnih besedil, med vsemi, kar jih premore naš komedijski repertoar. «17 Zamišljeni so kot spominska igra o nastanku in uprizoritvi prve slovenske posvetne igre, Linhartove Županove Micke. Ta je vključena $v$ tekst, ki ji je hkrati okvir. ${ }^{18}$ Komedija se godi »v lejti ta hude francoske prekucije $1789 .{ }^{19}$ in je slavospev vsem tistim, ki so pomagali pri rojstvu slovenskega gledališča. Zato je prvo dejanje načrt in boj za slovenski jezik, $v$ katerem naj bi zaživela literatura in gled̨ališče, drugo dejanje so zapleti in napoved slavnostnega trenutka, tretje dejanje pa pomeni, kako težko je pravzaprav igrati igro, komedijo, posebno še, ker so njeni igralci amaterji. ${ }^{20}$

Ker je nujno, da se oziramo na tekst, lahko ugotovimo, da je že Kreft razporedil $v$ delu tri pevske vložke. Žebre je sledil osnovni zamisli avtorja in napisal glasbo $\mathrm{k}$ besedilom $\mathrm{v}$ enajstem in šestnajstem "nastopu « prvega akta ter $\mathrm{v}$ peti »podobi« tretjega akta, kjer je dosegel muzikalni višek. Žebretova scenska glasba obsega 8 točk. Poleg že omenjenih, ki bi jih lahko imenovali vokalne $z$ instrumentalno spremljavo, je skladatelj napisal tudi instrumentalne dele. Zasedba, ki jo $\mathrm{v}$ posameznih točkah menjava, je razvidna iz notnega gradiva: 2 violini, violončelo, kontrabas, kitara, flavta, klarinet $\mathrm{B}$ in klavir.

Podrobna glasbena analiza je nastala na podlagi primerjave dveh virov. $\mathrm{V}$ skladateljevi zapuščini je notni material $\mathrm{z}$ instrumentalnimi parti, ki pa gradivu $\mathrm{v}$ arhivu Slovenskega gledališča iz Trsta niso priloženi. ${ }^{21}$

15 Gl. Šest O., Shakespeare in muzika, GL SNG Ljubljana, Opera, 1958-59, št. 1, 15.

16 Zaradi nepopolnih zapiskov in fragmentarnosti zasnove si ne moremo ustvariti prave slike.

17 Kreft B., Krajnski komedijanti, Ljubljana 1967, 293.

18 Prim. Kos J., Pregled slovenskega slovstva, Ljubljana 1975, 353.

19 Kreft B., Krajnski komedijanti, Ljubljana 1946.

20 Prim. Kreft M., Bratko Kreft in Krajnski komedijanti, GL SNG Maribor, 1974-75, št. 7, 183.

${ }_{21}$ Tržaški material je $\mathrm{v}$ zasnovi prepis ljubljanskega. Izdelan je za klavirsko spremljavo in pripravljen za predstavo 11.9. 1954. Da je bila morda uprizoritev izvedena samo s klavirsko scensko glasbo, je mogoče sklepati iz zapisa: „Jubilejna sezona Slovenskega narodnega gledališča za Svobodno tržaško ozemlje $v$ Trstu se je začela s slavnostno otvoritvijo dne 11 . septembra 1954, ko je gledališče $v$ tržaškem avditoriju kot premiero uprizorilo Kreftovo komedijo 'Krajnski komedijanti'. Pri uprizoritvi, ki jo je režiral Jože Babič, je sodeloval domala ves tržaški slovenski ansambel, glasbeno spremljavo Dimitrija Žebreta pa je izvajal prof. Karel Boštjančič. «(Gl. Gledališka kronika, GL SNG Ljubljana, Drama, 1954-55, št. 3, 66.) 
Številka $1^{22} \mathrm{~s}$ slavnostno prigodnim značajem obsega 16 taktov. Oblikovna določitev je preprosta: A, B (dve osemtaktji). Zadnjih 8 taktov je dejanska ponovitev prvih 8 taktov, razen kadence same. $V$ tem smislu si odgovarjata takta 7 in 15 . Takt $7 \mathrm{z}$ dominantnim sekundakordom D-dura, ki je osnovna tonaliteta, kadencira s toničnim sekstakordom in prehajalnim tonom $v$ toniko devetega takta. Takt 15 pa s popolno kadenco (tonični kvart-sekstakord, dominantni septakord) kadencira v toniko. Cel odstavek je pisan v akordih, ki jih prinaša zasedba dveh violin, violončela, kontrabasa, flavte, klarincta B in klavirja. Ta glasba je služila za uvod k samemu delu, saj nosi točka 1 na rokopisnem izvirniku oznako »Ouvertura ${ }^{23}$

V številki 2 je skladatelj predpisal ponovitev številke 1.

Številka 3 je Suzanina ${ }^{24}$ arijeta $z$ oznako »Tempo di Menuet « oziroma »Menuet « $v$ tržaškem gradivu. To je prva pevska točka, ki jo je določil že Kreft. Začenja $\mathrm{z}$ instrumentạlnim osemtaktnim uvodom. Sledi veliki A del, ki je v dvodelni obliki a b s tem, da obsega vsak del 8 taktov. B del je nekakšen sklepni del, sestavljen iz dveh štiritaktij. Ponavljalni znak narekuje ponovitev obeh delov, »da capo al fine « pa še ponovitev instrumenta!nega uvoda. Pevska linija obeh delov se začne s predtaktom. Če je $v$ delu A preprosta melodija namenjena interpretaciji preprostega teksta, pojmujemo B del kot Suzanino koloraturo, pri čemer se melodika giblje $\mathrm{v}$ razložitvah tonike in dominantnega septakorda D-dura. 2 violini, violončelo in klavir igrajo $v$ točki 3 in spremljajo pevski glas, ki prične: »Fantji! En lep cvet je ta...«. Suzana poje dve šestvrstični kitici. Vsaki sledi koloratura dveh štiritaktij, ki sta tonsko enaki. Ločita pa se $v$ dinamiki in načinu izvajanja. Prvi štirje takti so mezzoforte v legatu, drugi štirje pianissimo v portatu.

Avtor teksta prvih dveh pevskih vložkov ni Kreft. Krajnski komedijanti so pisani v stilu Linhartovega jezika ter ostalih razsvetljencev, in Kreft v razgovoru pravi: »...da se tudi dramaturško naslanjajo na njegovega 'Matička'. Zaradi treh pevskih 'vložkov' imenujejo nekateri igro 'vodvil' 25 ter prenašajo danes ta pojem nekam drugam, kajti potlej sta tudi Beaumarchaisov 'Figaro' in Linhartov 'Matiček' le vodvil, ker so $v$ obeh pevski vložki in oba se končata s kupleti. ...Ko sem pisal 'Krajnske komedijante', sem si dramaturško-tehnično vzel za zgled 'Figara', ki je vendar ena izmed najboljših 'razsvetljenskih' komedij, če že ne najboljša. Prav tako sem se dramaturško zgledoval po 'Matičku', zlasti še, ker sem hotel oživeti eno Linhartovo in eno Zoisovo pesmico, ki sem ju tudi vpletel v prvo dejanje. Pesnica 'Fantje! En lep cvet je ta...' je zares Linhartova (odnosno Linhartov prevod ali 'ponašitev' kakšne italijanske predloge), kitica 'Joj,dekleta' pa bi naj bil Zoisov prevod. Teh dveh torej nisem jąz 'skupaj spravil', vložil pa sem ju $v$ igro, da bi ju oživil skupaj $z$ njunima avtorjema.« ${ }^{26}$

22 V skladateljevem zapisu bi bila razčlenitev točke 1 tridelna: A B A in koda. Vsak del obsega 16 taktov (po dve osemtaktji). Zaključi se z osemtaktno kodo. Tržaški zapis ima B del prečrtan, kodo pa sploh izpuščeno. Oblikovna analiza prve točke je izvedena na podlagi tržaškega gradiva, ki je pregledneje zapisano.

23 Zaradi melodike v številki 1 pa bi lahko služila tudi kot slavnostni uvod k Suzanini ariji (točka 3), kjer se ta melodika $v$ grobih obrisih pojavlja v pevskem glasu.

24 Suzana Marranesijeva je eden glavnih likov komedije, »ena zares lepa laška pevkinja«, kot jo je označil Kreft v svojem delu.

25 Vaudeville, podrobno gl. $M E$ III, 1977, 645.)

26 Iz razgovora $z$ dr. Bratkom Kreftom, GL SNG Ljubljana, Drama, 195ん -57, št. 7, $253-254$. 
Številko 4 je skladatelj namenil »moškemu arijetu s kitaro«. Desettaktni kuplet pojejo dr. Piller, dr. Repič, dr. Mrak in Desselbrunner. Nad preprosto spremljavo kitare na toniki, dominanti in subdominantni paraleli nastopi $v$ drugem taktu vokalni del. Prične s predtaktom in se giblje $v$ majhnem obsegu v tercah (prvi in drugi glas). Preprosta melodika odgovarja tekstu šestvrstične kitice »Joj, dekleta, mlada leta...«, ki jo je prevedel Zois. ${ }^{27}$

Žebre je v četrti točki napevu podložil tudi Suzanin tekst, ki je tekst »Joj, dekleta, mlada leta...«s spremenjenim začetkom: »Caro mio! Mlada leta...«. To je določil že Kreft $v$ šestnajstem nastopu prvega akta, kmalu za moškim arijetom $s$ kitaro. Vendar ni razvidno, če je Suzana ta del res odpela. ${ }^{28}$

V številki 5, ki je v sedemnajstem nastopu prvega akta, zapoje Matiček sam ob spremljavi obeh violin, violončela, flavte in klavirja prvo kitico Suzanine arijete »Fantji! En lep cvet je ta...«.

Ob robu številk 6 in 7 si je Žebre zapisal: »Prenarejena originalna Linhartova zapiska «. Zato lahko ugotovimo, da sta mu za osnovo služili dve melodiji Linhartove pesmi. Objavljeni sta v njegovi nemško pisani mladostni zbirki »Blumen aus Krain «. ${ }^{29}$ Prva pesem »An Liebchen « ima dve štirivrstični kitici. Priložen ji je notni zapis s podloženim tekstom prve kitice. Tudi druga pesem »Lied «, ki je iz sedmih sedemvrstičnih kitic, ima notno prilogo in pod notami zapisano prvo kitico. Linhart je obe melodiji označil $z$ »Aria «. $Z$ nekaterimi spremembami ju je Žebre vložil v Krajnske komedijante.

Številki 6 in 7 (št. 6 odgovarja drugi Ariji, št. 7 pa prvi) imata značaj Menueta. Številka 6 je v 3/4 taktu Es-dura. Oblikovna gradnja je dvodelna $\mathrm{z}$ rahlim navdihom trodelnosti, tako da obsega vsak del 8 taktov. Crkovni zapis bi bil takšen: A B (b bi), s tem, da se A del na začetku še enkrat ponovi. Številka 7 je v A-duru in prav tako $v$ trodobnem taktu. Ima obliko $A \mathrm{~B} \mathrm{~B}_{1}$, ker se $\mathrm{B}$ dela razlikujeta $\mathrm{v}$ kadenci.Vsak del obsega 8 taktov. Harmonizacija je preprosta in služi namenu te glasbe. $V$ obeh instrumentalnih točkah uporablja skladatelj isto zasedbo: 2 violini, violončelo, kontrabas, flavto, klarinet B (ni razvidno, ali je tudi v št. 7) in klavir.

V številki 8 , ki je mišljena kot slavnostna točka komedije, odpojejo vsi glavni igralci nekaj za srečni konec. $V$ melodiki spominja na uvodno številko 1 , pa tudi na številko 3. Vokalni del ima solistične speve, ki se vrstijo. V tem smislu je sklepna točka razmeroma oblikovno prosto, vendar jasno periodizirana. Po dveh taktih instrumentalnega uvoda $v 3 / 4$ taktu sledi prvi del, ki je sestavljen iz treh osem-

27 Kreft B., Italijanska dela v slovènskem gledališču, GL SNG Ljubljana, Drama, 1940 -41, št. 19, 1654. V tem članku je avtor med drugim zapisal: »Ohranjeni so podatki, ki pričajo, da se je morala gledališka družina ravnatelja Bartolinija obrniti prej na ljubljansko gledališko upravo (1. 1788. v jeseni), preden je smela angažirati nekaj novih pevcev, s katerimi je nastopila $v$ Ljubljani. Gledališko vodstvo pri krajnskih stanovih je nato izbralo barona Zoisa, očividno kot najboljšega poznavalca in strokovnjaka, da pove svoje mnenje o novih pevcih. Prav gotovo je bila tudi njegova ideja, da so italijanski operisti v Ljubljani včasih zapeli kakšno arijo tudi v slovenščini. Ohranila sta se dva taka primera: ena arija v prevodu barona Zoisa, (»Oj,dekleta «), druga pa v prevodu A. Linharta (»Hej, fantji!«).

28 Morda ga je samo izgovarjala, kajti napevu v tržaškem gradivu njen tekst ni podložen.

29 Zbirka ima naslov: »Blumen aus Krain. Für das Jahr 1781, Laybach, gedruckt mit Egerschen Schriften«. Hrani jo NUK Lj. Gl. tudi A T. Linhart. Zbrano delo, I, 1950, $219-223$. 
taktij. Prične Lucija. ${ }^{30}$ nato zapojejo vsi, vstopi Suzana in vsi skupaj zaključijo prvo osemtaktje. V drugem se izmenjata grof in Japelj, $v$ tretjem pa Makovic in Micka. Drugi del je v 2/4 taktu, v katerem se osma točka tudi zaključi. Obsega 21 taktov. Repič in Vodnik odpojeta po + takte, Matičku pa je skladatelj glede na tekst namenil 11 taktov. Dodana sta še 2 takta kot sklep. Vsi zapojejo: »Vivat! Vivat! Vivat!« Začne tretji del, ki ima obliko a b a. Prvo osemtaktje je Suzan̉in spev. Drugih 8 taktov je njena koloratura kot neke vrste medigra, ki jo v tretjem osemtaktju nadaljuje Suzanin spev, končajo pa vsi. Sklepni del, ki obsega 16 taktov, odpojejo 4 takte vsi, nato se zvrstijo Repič, Mrak in Piller. Še enkrat zapojejo vsi skupaj in štiritaktni instrumentalni del zaključi komedijo.

Harmonizacija je preprosta. Podrejena je pevski liniji, ki jo akordično podpira. Temelji na razloženih glavnih stopnjah. Mestoma se pojavijo prehajalni toni. Zasedba, ki jo je Žebre uporabil, kaže, da se je prilagajal namenu in značaju besedila. Instrumentalni part obsega 2 violini, violončelo, kontrabas, flavto, klarinet $B$ in klavir.

Avtor besedila je Kreft. Sam pravi: »Ker sem se tudi pri zaključku komedije hotel držati načina, kako Beaumarchais zaključuje svojega 'Figara' in po njem tudi Linhart 'Matička', sem pač moral v Linhartovem stilu in jeziku zložiti besedilo za zaključno petje. Vsekakor sem se pri tem zgledoval bolj po Linhartovih stihih v 'Matičku' kakor po Beaumarchaisovih. « ${ }^{31}$

Žebretova glasba povsem ustreza tekstu. Jasna periodizacija, preprosta instrumentacija in spevne melodije pripomorejo $\mathrm{k}$ vzdušju komedije, »katere glavni namen je biti - vesela, humorna, linhartovska hvalnica utemeljitelju novejše slovenske dramatike in gledališča, vsem razsvetljencem, prav tako pa slovenskemu jeziku in slovenski gledališki umetnosti sploh «. ${ }^{32}$ Če je moral Žebre v Krajnskih komedijantih dosledno slediti osnovni zamisli avtorja in se tudi stilno vključiti v dogajanje komedije, mu je Skakespearova tragedija Romeo in Julija nudila veliko več svobode. Bila je hkrati njegov prvi prispevek na področju gledališke glasbene tvornosti.

Analiza je nastala na podlagi notnega gradiva $\mathrm{v}$ skladateljevi zapuščini in $\mathrm{v}$ arhivu Slovenskega gledališča iz Trsta. Oba vira imata priložene instrumentalne parte. Ljubljansko gradivo je mogoče razdeliti na tri skice: A, B in C. Skica A obsega 9 točk; pri tem imajo nekatere dodatne oznake a, b, c, pa tudi d. Iz orkestralnega materiala je mogoče sklepati, da je bila to prvotna verzija glasbe, ki je bila izvajana v sezoni 1940/41. Zasedba flavte, klarineta v B, trobente v B, malega in velikega bobna, violine in klavirja, najbrže pod vodstvom dirigenta, kaže, da se je glasba izvajala »živo « za sceno ali v prostoru za orkester. Izvajalci so se s preglednostjo razvrstitve točk pri igranju nekoliko borili. $\mathrm{O}$ tem pričajo pregledi točk ob robu materiala, ki so jih zapisali izvajalci sami, pa tudi hudomušni pripis violinista na svojem partu. Slednji je na koncu parta pripisal datum premiere (21. IX. 1940 ) in petindvajseto izvedbo (18. IV. 1941). V skici A imajo posamezne točke oznake tempa in le redko dinamične označbe ter označbe zasedbe. Skica B ima poleg tega drugačno oštevilčenje. Razdeljena je v dva dela, ki obsegata 24 točk. Točke nosijo programske naslove, ki omogočajo določitev mesta izvajanja $v$ gledališkem delu. Verjetno gre pri skici $\mathrm{B}$ za izpopolnjeno verzijo glasbe $\mathrm{k}$ Romeu in

\footnotetext{
$30 \mathrm{~V}$ tržaškem gradivu ima prvi spev Suzana.

31 Iz razgovora $z$ dr. Bratkom Kreftom, GL SNG Ljubljana, Drama, 1956-57, št. 7, 32 Ibid., 254.
} 254. 
Juliji, morda za mariborsko izvedbo jeseni 1951. Skice C v tem smislu ni mogoče opredeliti.

Tržaški material, ki ima priloženo partituro in instrumentalne parte, odgovarja skici B. Iz rokopisa je mogoče sklepati, da ga je izdelal skladatelj sam in pripravil za predstavo 1. 8. 1952. Podrobni glasbeni analizi služi za osnovo skica $B$.

Prvi del začenja $\mathrm{z}$ uvodnim pozivom, ki je Maestoso. V skicah $\mathrm{A}$ in $\mathrm{C}$ obsega 7 taktov, skica B pa ima takt več. Ljubljanski zapis zahteva zasedbo dveh trobent in malega bobna. Na tržaški predstavi, ki so jo dajali na prostem, na stadionu »Prvi maj «, ${ }^{33}$ je bil orkester mnogo večji. ${ }^{34}$ Tako je Žebre v prvi točki uporabil 2 trobenti v B, 2 rogova v F, 2 violini, violončelo, kontrabas, tamburin in timpane. Uvodni poziv se giblje v B-duru, ki pa nima tona es. Lahko bi bila lidijska tonaliteta na tonu b. V 5. taktu vključi ton des, ki stemni začetno lidijsko b-tonaliteto. Kljub neodločnosti daje prva točka vtis zaključka na dominanti.

Sledi nastop k prologu. ${ }^{35}$ Tri takte Allegretta je skladatelj določil dvema rogovoma in dvem trobentam, medtem ko ima tržaška partitura dve trobenti in prvi rog. Na ostinatnem motivu roga prinasa prva trobenta kvartne motive, druga trobenta pa nekaj dopolnilnih vmesnih tonov. Motiv se giblje $v$ tonaliteti F-dura in konča na dominanti.

Številko 3 je skladatelj označil z odstopom in ji predpisal ponovitev številke 2 .

Četrta točka je zaključek uvodnega poziva in zato ponovitev prve točke.

Flavto, klarinet, 2 trobenti con sordino ( $\mathrm{z}$ dušilcem) in obe violini je Žebre uporabil v peti točki in jo imenoval »Pretep in nastop kneza «. ${ }^{36}$ Šesttaktni motiv v Allegro tempu se po potrebi lahko ponavlja. Harmonsko ogrodje tvorita violini in dušeni trobenti $\mathbf{z}$ - -molovim kvartsekstakordom. Flavta se giblje oktavo višje $s$ tipičnim ostro ritmiziranim motivom $v$ tritonusu, ki se kasneje razgiblje še navzdol. Tremolo violin s spodnjimi menjalnimi toni f-mol ogrodja in stalno se ponavljajoči ritmični motiv $v$ trobentah disonantno razgibljeta harmonsko ogrodje. Iz tržaškega orkestralnega materiala je razvidna zasedba flavte, klarineta $\vee B$, dveh trobent $v B$ con sordino, timpanov, dveh violin, violončela in kontrabasa. Točka obsega 8 taktov, pri čemer sta prva dva nekakšen uvod, ostalih šest pa odgovarja skici B.

Šesta točka je nastop kneza. Dve trobenti in dva rogova $v$ ljubljanskem ter dve trobenti in prvi rog v tržaškem zapisu igrajo 6 taktov. Tonaliteta As-dur nekoliko spominja na paralelni mol zaradi ponavljajočega $f-c$ v zgornjih glasovih. Ker je konec na dominanti. je osnovna tonaliteta vendarle As-dur. Rogova prinašata na tonu es ostinatni ritmični motiv.

Sledi odstop kneza, ki je ponovitev številke 6 .

»Večerni intermezzo in nato lutnja « nosi naslov osma točka v skici B, ki je brez oznake zasedbe. Motiv lutnje je zapisan pri točki 12 . V skici A je isti odlomek kot točka 3 a, vendar brez lutnje. skica $C$ te točke sploh nima. Iz klavirskega parta in iz ostalih partov $v$ ljubljanskem materialu je razvidna zasedba flavte, klarineta $v \mathrm{~B}$,

33 Gl. GL Slovenskega gledališča v Trstu, 1951-52, jubilejna številka.

34 Sodelovalo je dvajset do trideset izvajalcev, med katerimi so bili tudi študentje akademije. (Podatek je iz razgovora $\mathrm{z}$ J. Babičem.)

35 Tragedija prične s prologom. V njem naj bi nastopil Kor (zbor), ki je odmev stare grške tragedije. Vendar ga pri uprizoritvah Romea in Julije po navadi nadomesti en sam igralec. Naloga prologa je ustvariti neposrednejši stik z gledalci in vzbuditi večje zanimanje publike. (Prim. W. Shakespeare, Romeo in Julija, 197ł, Opombe, str. 121)

36 Težko je določiti mesto $v$ gledališkem delu točkama 5 in 6 . Obe namreč označujeta v naslovu nastop kneza. Shakespeare je $\mathrm{v}$ prvi prizor prvega dejanja vključil ulični pretep in samo en nastop kneza s spremstvom. 
violine in klavirja. Klavir izvaja spodnji figurativni glas unisono $\mathrm{z}$ violino, pa tudi srednjega, ki je poenostavljeni part klarineta. Oblikovna določitev odlomka je preprosta. »Večerni intermezzo«, Allegretto, je šestnajsttaktna dvojna perioda, sestavljena iz dveh osemtaktnih delov, a in b. Pri tem gre za dosledno ponavljanje dvotaktij. Spodnji glas nakazuje toniko, dominanto in tudi subdominanto tonalitete G-dura, vendar ta tonaliteta v zgornjem glasu sploh ni izražena. Pojavlja se tudi ton gis kot prosti melodični ton. Del a konča na dominanti, b del pa na toniki G-dura. Priključi se osemtaktni odstavek za lutnjo v e-molu. Nad basovsko ostinatno spremljavo, ki sicer ni čisto dosledna, se odvija preprosta melodija. Opisuje toniko e-mola in subdominanto $\mathrm{z}$ dodatno seksto. Dominanta $\mathrm{v}$ sedmem taktu je molovska, d-fis pa spominja na durovsko dominanto. $V$ tržaškem gradivu je »Večerni intermezzo « $v$ izvedbi flavte, klarineta $v B$, dušenih violin, pri čemer ima prva violina solo, in violončela.

Peti prizor zaključuje prvo dejanje tragedije. Vanj je Shakespeare vključil godbo in ples, kjer se srečata Romeo in Julija. Žebre mu je glasbeno sledil in deveto točko pričel s pozdravom Capuleta. Dve trobenti in dva rogova unisono v skici $\mathrm{B}$ ter dve trobenti in prvi rog $\mathrm{v}$ tržaški partituri prinašajo štiritaktni odstavek $\mathbf{v}$ G-duru s kvintakordi, ki so ostro ritmizirani. Sledi Paduana. ${ }^{37} \mathrm{~V}$ skici B je njen nastop samo omenjen, skica $C$ pa je sploh nima. Zato je bila analiza možna na podlagi skice $A$ in instrumentalnih partov, kjer je kot točka 6 , ter na podlagi tržaškega materiala.

Ples je v veliki pesemski obliki A B A. Vsak del je tridelen a b a, sestavljen iz treh osemtaktij. Melodika ni nič drugega kot motiv lutnje iz osme točke. Del a se giblje v okviru e-mola. Osrednji B del preide brez modulacije v tonaliteto G-dura. Tretji del je ponovitev prvega dela. Tokrat je tonalnost najbolj jasno izražena, pa . tudi periodizacija in harmonizacija sta preprosti, morda zaradi hotene imitacije starega plesa. Skladatelj je želel doseči kontrastnost v tem, da je A delu določil 4/4 takt in šele B del zapisal v 3/4 taktu, kot je za ta ples značilno. Vendar pa tempo izvedbe nikjer ni naznačen. Poleg tega je spremljava v B delu v tekočih osminkah, šestnajstinke $\mathrm{v}$ melodiji pa so mišljene skoraj kot okrasne. Iz materiala je razvidno, da je bila zasedba sledeča: flavta, klarinet $\mathrm{v} B$, violina in klavir. Tržaška partitura pa prinaša flavto, prvi klarinet in morebiti drugega, obe violini, violoncelo in kontrabas.

»Odhod s plesa « nosi naslov številka 10 v skici B, ki jo izvajata flavta in klarinet $\mathrm{v} 8 \mathrm{~s}$ spremljavo dveh rogov in klavirja. Isti odlomek je v skici A pod točko $3 \mathrm{~d}$, Marciale, a brez mesta uporabe. Instrumentalni parti kažejo, da je zasedba te točke: flavta, violina in klavir $\mathrm{v}$ unisonu, oktavo nižje klarinet in trobenta unisono ter boben. Klavir igra melodijo $v$ isti legi kot klarinet in trobenta. $V$ tržaškem gradivu je uporabljena flavta, čeprav $v$ partituri ni zapisana. Devettaktni odstavek se giblje $\mathrm{v}$ tonaliteti $\mathrm{F}$-dura, toda $\mathrm{z}$ miksolidijskim navdihom zaradi tona es, $\mathrm{s}$ katerim odstavek tudi konča. Ostinatna spremljava v skici A opisuje toniko in dominanto.»Stalni ritmični obrazec je v klavirskem partu, v skici B in tržaški partituri pa je nekoliko spremenjen. Tržaški zapis pa ima poleg tega tipične skoke basa v dveh kvintah, ki opisujejo hkrati toniko in dominanto. Motiv se nespremenjen ponavlja vseh 9 taktov. Nad njim imamo ponekod menjalne in prehajalne tone. Iz skladateljevega pripisa je razvidno, da se odstavek lahko ponavlja.

37 Več izrazov označuje ta ples: padovana, paduana, pavana. Podrobno gl. geslo Pavana, $M E$ III, $1977,51$. 
Mrmrajoči ženski zbor, ki ga sestavljajo prvi in drugi sopran ter alt, nastopa $v$ točki 11. Tonaliteta je F-dur. Oblikovno bi stavku lahko določili trodelnost A B A1, pri čemer je prvi del osemtaktna perioda, srednji štiritaktna medigra, tretji del pa ponovitev A dela s spremenjenim zaključkom. Soprana stopata $\mathbf{v}$ tercah in opisujeta $v$ glavnem tonični trizvok $z$ menjalnimi toni. Spremlja ju alt večinoma $v$ ostinatu. Od tona f se oddalji samo za terco navzdol, razen v enajstem taktu, ko doseže ton g. Pri tem stopa z zgornjima glasovoma v vzporednih kvartsekstakordih in opiše dominanto. Kakšna je bila zasedba na tržaški predstavi, je težko pojasniti. Vokalni parti so gradivu priloženi, vendar prinaša partitura enajsto točko $\mathrm{v}$ izvedbi godal (I. in II. violina, violončelo). Zagotovo pa se je izvajalo samo 12 taktov.

$V$ drugem prizoru drugega dejanja tragedije je znamenita »balkanska scena«. Tako je tudi Žebre naslovil dvanajsto točko v skici B. Skica A ima ta primer kot 3 c. Odstavek v Andante tempu obsega 10 taktov, instrumentalni parti pa imajo takt manj. Sprememba je le v zaključku. V skici C je odstavek dvanajsttakten, ker ga pričenja kitara $\mathrm{z}$ dvema taktoma uvoda. Melodijo igra flavta solo ob spremljavi klarineta, violine in klavirja. Stavek, ki bi ga lahko določili v $\mathrm{G}$ tonaliteti, začne na tonični paraleli in kromatično prehaja $v$ dominanto, subdominantno paralelo in toniko. Proste trizvočne zveze, ki so podane v basu z osnovnim tonom in kvinto, so opisane $\mathrm{z}$ zgornjo vodilno melodijo flavte in s figurativnim srednjim glasom, ki je nekoliko spremenjen v skici $A$. Tržaški zapis kaže izvedbo v počasnejšem tempu, Larghetto, $\mathrm{z}$ uporabo flavte, klarineta, obeh violin, ki v partituri manjkata, obeh rogov, violončela in kontrabasa.

»Nastop in odstop Petra«, sluge Julijine dojilje, sodi v četrti prizor drugega dejanja. Njegova vloga je kratka. Spremlja Julijino dojiljo, ko le-ta išče Romea. Allegretto stavek se giblje v 6/8 taktu G-dura. Razdeljen je na tri dele A B A, pri čemer obsega vsak 8 taktov. V skici A, kjer je kot točka 4, v skici B kot točka 13 in v skici C, kjer nima številke, zahteva skladatelj flavto ob spremljavi violine, klavirja in bobna; za razliko od tržaške zasedbe, kjer je Petrov nastop izvajala flavta solo.

Štirinajsto točko skice B pričenja šesttaktni odstavek, namenjen orglam, s katerim prehaja skladatelj $\mathrm{v}$ finale. Izvaja ga harmonij. Pomotoma je odstavek zapisan $\vee 6 / 4$, namesto $\vee 3 / 2$ taktu. Tonalnost je razmeroma zabrisana. Lahko pa jo pojmujemo kot lidijski C-dur z zaključkom na dominanti.

Nanj se naveže enajsttaktni odstavek v 4/4 taktu. Mišljen je kot zaključna glasba k drugemu dejanju tragedije. Stevilki 5 v skici A in 14 v skici B ter instrumentalni parti kažejo uporabo flavte, klarineta, trobente, violine, klavirja in bobna. V tržaškem zapisu je zasedba številnejša: flavta, prvi in drugi klarinet, dva rogova, dve trobenti in obe violini, violončelo, kontrabas in timpani. Flavta in klarinet pa sta $v$ izvedbenem materialu ponekod črtana. Tonaliteta je G-dur. Harmonsko podlago tvorijo tonika, tonična paralela, dominanta in subdominanta. Melodija prosto opisuje razložitve navedenih funkcij. Vmes so dodani tuji toni.

Drugi del glasbe $\mathbf{k}$ Romeu in Juliji začne s petnajsto točko. $\mathbf{V}$ njej je Žebre uporabil orgelski motiv prejšnje točke. Tudi številki 16 in 17 sta ponovitvi, in sicer točke 6 , saj označujeta nastop in odstop kneza.

Sledi »Sprevod Tybalta « iz prvega prizora tretjega dejanja. Tybalt pade v spopadu z Romeom, ki maščuje prijatelja. Trobenta solo, klarinet, violina, veliki boben in klavir izvajajo šesttaktni odstavek, ki je v skici A kot 3 b. V tržaški izvedbi je zasedba drugačna: dva klarineta, ki igrata melodijo; dva rogova in dve trobenti, 
ki sta lahko dušeni, tamburin, dve violini, violončelo in kontrabas. Melodija v zgornjem glasu prinaša tone naravnega f-mola. Giblje se večinoma v karakterističnih razponih kvarte: f-b-es. Nad prazno kvinto v basu (f-c) se zvrstijo v srednjih glasovih zadržki v vzporednih tercah, ki se vzporedno tudi razvezujejo: ges-b, f-as. Ponavljajoča se tona $f$ in es $v$ glasu pod melodijo dopolnjujeta gosto harmonijo, ki izrazno odgovarja značaju pogrebne koračnice.

Številka 19 je ponovitev taktov Tybaltovega spremstva.

$\mathrm{V}$ petem prizoru tretjega dejanja se sliši ptičje žgolenje. Dani se in Romeo se poslavlja, ker mora $v$ izgnanstvo. Nad tremolom dveh violin se odvija melodija flavte in klarineta, ki s trilčki in drobnimi notami oponašata ptičje žgolenje. Za podlago dvanajsttaktnemu stavku služi enakomerna akordična figuracija klavirja, s katero postane harmonska realizacija zelo gosta.

Juliji grozi prisilna poroka s Parisom. Reši jo lahko samo smrt. Da bi preprečil njeno namero, ji brat Lorenzo ponudi uspavalni napoj, ki ga Julija v tretjem prizoru četrtega dejanja spije. Pred tem blodi in premaguje grozo ob misli, da bo živa zakopana. Štirje takti odstavka so zapisani v $3 / 4$, ostali štirje pa v $4 / 4$ taktu. Težko je zbrati pravo akordično strukturo. Res pa je, da glasba $v$ drugẹm štiritaktju močno spominja na točko 18 . Podobnost je mogoče pojasniti, ker se Juliji v blodnjah prikaže Tybaltov duh. Ljubljanski zapis ima ta primer samo v skici B pod točko 21 , kjer ni oznak zasedbe. Tudi v tržaškem zapisu se izvedbeni material razlikuje od skice. Zato lahko le domnevamo, da je prvo štiritaktje izvajala flavta solo, s kromatičnimi postopi, ob spremljavi obeh violin. V drugem štiritaktju pa naj bi se pridružili ostali instrumenti: klarinet, dve trobenti s sordinom, dva rogova $\mathrm{v} F$, violončelo in kontrabas.

Četrti prizor četrtega dejanja se godi v Capuletovi hiši. Priprave za poroko so pri kraju in Capulet že sliši grofa Parisa, ki prihaja z godbo. Tukaj je Žebre vključil dvaindvajseto točko. V skici B ji je dal naslov »Svatovska godba«. Isti primer je tudi v skici A kot številka 8 in v skici C. Stavek je Allegro v trodelni obliki A B A. Vsak del obsega 8 taktov. A del ima v basu ostinatno spremljavo, ki temelji na toniki in dominanti B-dura. Srednji del je kontrasten. Skladatelj je uporabil ton des, ki učinkuje kot stemnitev. Ostinatna oblika se nadaljuje, le da tvorita podlago subdominanta in dominanta temeljne tonalitete. Tretji del je ponovitev A dela s spremenjenim zaključkom. Zasedba je različna. $\mathrm{V}$ ljubljanskem gradivu prinašata melodijo flavta in delno trobenta v B, spremljajo pa klarinet, violina, klavir in boben. Iz tržaškega zapisa je mogoče razbrati nastop flavte in dveh trobent, ki v partituri manjkata, klarineta, obeh violin, violončela in kontrabasa. Samo v partituri pa je zapisan še part kitare.

Julijino spanje je podobno smrti, zato je v peti prizor četrtega dejanja vključen pogrebni sprevod. V enajsttaktnem odstavku skice B se v prvih petih taktih izmenjata $2 / 4$ in $3 / 4$ takt. Melodijo, ki se spušča od $d^{2}$ do es ${ }^{1}$ in obstane na $d^{1}$, prinesejo unisono flavta, violina in klavir. Sledi 6 taktov v $4 / 4$ taktu. Nad tonom d, ki tvori podlago, se giblje melodija flavte, sestavljena iz tonov a in $\mathrm{g} \mathrm{s}$ spremembo na zakljucku. V srednjih glasovih je ostinatna figura disonančno podprta $z$ vzporedni kvintakordi. Odstavku bi težko določili tonaliteto. Lahko pa rečemo, da je tonalno območje d. Dolžina triindvajsete točke je $v$ materialu različna. Tako obsega točka 7 v skici A 10 taktov, isti primer v tržaškem zapisu pa 12 taktov. Ljubljansko gradivo uporablja flavto, klarinet, trobento, violino, klavir in boben. 
Tudi tržaška partitura prinaša polno zasedbo: flavto, dva klarineta, dva rogova in dve trobenti, timpane, obe violini, violončelo in kontrabas.

Sprti rodovini Montegov in Capuletov sta povzročili tragedijo Romea in Julije. Sovraštvo je preprečilo združitev obeh, ki sta se imela rada. Monteg in Capulet si podata roke, ker bosta zdaj lahko uživala sadove sprave. Skica B se razlikuje od skice $A$, skice $C$ in instrumentalnih partov. Na podlagi štiriindvajsete točke v skici B in v tržaškem zapisu lahko razčlenimo osemtaktni odstavek Maestoso. Tonaliteta je As-dur. Ostinatna figura v basu, ki v vzporednih kvintah opiše toniko, tonično paralelo in subdominanto osnovne tonalitete, se ponavlja 4 takte. V naslednjem štiritaktju imamo deloma opraviti s podobno ostinatno obliko v strukturi tonika, subdominanta, dominanta. Nerazumljiva je pisava kadenčnega akorda nad tonom es s fis-h-d, ker bi morda pričakovali zapis es-ges-ces $\mathrm{z}$ dodatnim d. Instrumentalno zasedbo je mogoče določiti le iz tržaškega gradiva, kjer je flavta uporabljena po potrebi, melodija zaupana deloma klarinetu in dušenima trobentama, spremljava pa v vlogi dveh rogov, tamburina, prve in druge violine, violončela in kontrảbasa. Tematika prvih štirih taktov finala je identična s tematiko šeste točke, kjer nastopi knez. Utemeljitev je mogoča, ker se Shakespearova tragedija Romeo in Julija zaključi z nastopom kneza, ki mu je bila dana naloga razsodnika.

Notna skica k Alessijevi Katarini Medičejski nosi datumsko oznako 23. 9. 1941. Premiera je bila že čez štiri dni 27. 9. 1941. Težko je sklepati na karkoli. Res pa je, da si iz nepopolnih zapiskov in fragmentarnosti zasnove ne moremo ustvariti prave slike.

Skica obsega dvanajsttaktni odstavek s predpisano zasedbo trobente in bobna. Iz motivike je možno razbrati, da gre za slavnostni signal, ki se ponavlja. Kje naj bi bila uporabljena tudi skicirana gavotta in kako je bila zamišljena instrumentacija, ni razvidno. Priložena sta instrumentalna parta druge violine in viole.

Klavirski koncept scenske glasbe k Hamletu obsega 22 točk, tako da se nekatere ponavljajo $z$ drugo številčno oznako. Iz skice ni mogoče ugotoviti, kam $v$ dramskem tekstu posamezne točke sodijo. Pri nekaterih je zapisana zasedba oziroma pripisana tudi oznaka za tempo izvedbe. Ponekod oboje manjka, ali pa je zasedba le delno naznačena.

$\mathrm{K}$ temu sta dodani skici Maestoso. Prva $\mathrm{z}$ delno naznačeno zasedbo, druga $\mathrm{z}$ izdelano partituro. Ista zasedba je še v preglednejši skici, toda brez oznake tempa. Pač pa ima skica naslov »Fanfara «. Da ga je pripisal Uroš Krek, ki je po skladateljevi smrti urejeval njegovo zapuščino, kaže opazka na robu partiture. Iz tega in iz motivike lahko ugotovimo, da gre za gradivo k prvi točki scenske glasbe. V notnem materialu so priloženi tudi instrumentalni parti štirih trobent v $B$, štirih rogov v F, treh pozavn (trombonov, kot je zapisal Žebre), tube in timpanov z oznako Maestoso.

Če je mogoče iz ohranjenega notnega gradiva označiti scensko glasbo Demetrija Žebreta, potem lahko trdimo, da so vse glasbene točke odstavki s presenetljivo pravilno periodizacijo. Zaslediti je motivično gradnjo od dvotaktij, štiritaktij do dvojne periode. Skladatelj se je najbrž zavedal, da mora v najkrajši obliki z jasno členjeno motiviko ustvariti vzdušje $h$ gledališkemu delu. Zagotovo je vedel, da njegova glasba ni sama sebi namen, pač pa je glasbeni prispevek k delu samem. $Z$ glasbo $k$ Romeu in Juliji mu je to vsekakor uspelo. Ni se posluževal zunanjih ilustrativnih prijemov. Učinek je hotel doseči s čistimi glasbenimi sredstvi. 
Melodije lahko opredelimo kot popolnoma tonalne, včasih prosto tonalne, ker jih obravnava prosto $\mathrm{v}$ odnosu s podlago. Njegov priljubljeni interval je kvarta. Vse polno jih ima, seveda predvsem tam, kjer je uporaba tega intervala smiselna (fanfarni motivi). Ostinatne oblike v spodnjih glasovih in vzporedni premiki so pri njem pogosta sredstva. Za zgoščevanje zvoka se Žebre poslužuje prostega dodajanja intervalov $\mathrm{k}$ sicer funkcijsko lahko opredeljivim akordom.

V primerjavi z ostalim, zlasti zgodnjim kompozicijskim opusom, kjer je sledil radikalnim stilnim tokovom, nas njegova odrska glasba preseneča. Krajnski komedijanti so ga zares vezali $\mathrm{z}$ besedilom in zgodovinskim ozadjem, zato pa je imel v Shakespearovi tragediji pri izbiri sredstev glasbenega izražanja prosto pot. Zakaj je ni uresničil v smislu tedanjega »novega $v$ glasbi, bi bilo mogoče pojasniti, da je kmalu po vojni nehal komponirati, ko je že tudi ublažil svơje stališče. ${ }^{38}$ Poleg tega je glasba le sestavni del gledališkega dela in ima skladatelj vlogo soustvarjalca, ki mora pri uresničitvi upoštevati tudi zamisli svojih gledaliških sodelavcev.

Odgovornost skladatelja za scensko glasbo ni samo, kar se tiče časovnega zgodovinskega sloga, velika. Večja je, ko gre za pojmovanje vsebinskih zahtev in razpoloženj. ${ }^{39}$ Demetrij Žebre je bil kot operni dirigent tesno povezan $\mathrm{z}$ gledališčem in je zato vedel, kaj scenska glasba zahteva, a vselej ni mogel realizirati, kar je morda želel.

Izvedbe dramskih del s scensko glasbo Demetrija Žebreta: ${ }^{40}$

W. Shakespeare: Romeo in Julija

21. 9. 1940. Drama SNG Ljubljana. Sezona 1940/41. 26 predstav

21. 5. 1942. Drama SNG Liubljana. Sezona $1941 / 42.8$ predstav

25. 11. 1951. Drama SNG Maribor. Sezona 1951/52. 23 predstav

1. 8. 1953 - 15. 8. 1952. SG Trst. Sezona 1951/52. 7 predstav

R. Alessi: Katarina Medičejska

27. 9. 1941. Drama SNG Ljubljana. Sezona 1941/42. 10 predstav

W. Shakespeare: Hamlet

5. 10. 1941. Drama SNG Ljubljana. Sezona $1941 / 42.13$ predstav

30. 10. 1942. Drama SNG Ljubljana. Sezona 1942/43. 13 predstav

C. Goldoni: Kavarnica

29. 10. 1943. Drama SNG Ljubljana. Sezona 1943/44. 10 predstav

B. Kreft: Krajnski komedijanti

21. 10. 1948. Drama SNG Ljubljana. Sezona 1948/49. 36 predstav

38 Prim. Žebre D., ME III, 1977, 773.

39 Prim. Slavec Maša, Nov »Hamlet« se nam predstavi, SN LXXIV, 1941, št. 229, 5.

40 Podatki o izvedbah so $\mathrm{v}$ gradivu, ki ga hrani ljubljanska Narodna in univerzitetna knjižnica: Repertoar slovenskih gledališč 1867-1967, Ljubljana 1967; Gledališki list SNG v Ljubljani, Drama, 1940 - 1975; Gledališki lisî Mestnega gledališča ljubljanskega, 1966/67; Gledališki listi SNG v Mariboru, Drama, 1946-1975; Gledališki listi Slovenskega ljudskega gledališča v Celju, 1945-1958; Gledališki listi Prešernovega gledališča v Kranju, 1945-1949 in 1950 - 1957; Gledališki listi Gledališča Slovenskega primorja v Kopru, 1952-1958; Gledališki listi Slovenskega gledališča v Trstu, 1945-1954, 1955-1961 in 1962-1967. 
22. 10. 1949. Drama SNG Ljubljana. Sezona 1949/50. 18 predstav

15. 11. 1949. SLG Celje. Sezona 1949/50. 17 predstav

5. 12. 1951. Drama SNG Ljubljana. Sezona 1951/52. 24 predstav

18. 10. 1952. PG Kranj. sezona 1952/53. 22 predstav

11. 9. 1954. SG Trst. Sezona 1954/55. 17 predstay

21. 10. 1954. GSP Koper. Sezona 1954/55. 21 predstav

28. 12. 1956. Drama SNG Ljubljana. Sezona 1956/57. 29 predstav

26. 1. 1958. Drama SNG Ljubljana. Sezona $1957 / 58.4$ predstave

16. 4. 1962. Drama SNG Ljubljana. Sezona 1961/62. 16 predstav

11. 6. 1962. Prenos RTV

24. 6. 1962. Gostovanje v Križankah (»Festival«)

18. 1. 1964. Drama SNG Maribor. Sezona 1963/64. 23 predstav

25. 3. 1967. MGL. Sezona 1966/67. 41 predstav

1974 1975. Drama SNG Maribor. Sezona 1974/75

\section{W. Shakespeare: Kralj Lear}

4. 11. 1949. Drama SNG Ljubljana. Sezona i949/50. 21 predstav

\section{J. Kulundžić: Človek je dober}

17. 6. 1953. Drama SNG Ljubljana. Sezona 1952/53. 12 predstav

\section{SUMMARY}

Demetrij Žebre's compositional output contains also works connected with the theatre. In the years 1940 - 1953, the Drama House of the Slovene National Theatre in Ljubljana staged seven works for which he wrote incidental music. The research is focused on the music for two plays - Kreft's »Carniolian Comedians« and Shakespeare's »Romeo in Juliet«. The reasons for the analysis of these two pieces of instrumental music can be stated as follows: they comprise the greatest amount of survived material, which includes also instrumental parts; apart from that, these are the two pieces which have been most frequently performed.

The »Carniolian Comedians « are written in the idiom of Linhart's language as well as in that of other enlightened authors. Žebre followed the basic idea of the author and adapted himself stylistically to the happening in the comedy. Clear periodisation, simple instrumentation and melodious tunes contribute to the overall atmosphere.

Shakespeare's tragedy »Romeo and Juliet« offered Žebre much more freedom. Its music represents Żebre's first contribution to the field of the theatre. And, as an opera conductor, Zebre was always in close contact with the theatre. He was aware of the fact that his music was nót a l'art pour l'art affair, but a contribution to the work itself. All music numbers reflect a surprisingly correct periodization. Motivic work can be followed from two-bar and four-bar phrases up to double periods. Melodies are either completely tonal or, sometimes, freely tonal due to their treatment as regards the bass. Ostinato forms in lower parts and paralel progressions are quite frequent. Added-note chords, which are functionally unquestionable, contribute to the intensification of sound.

In comparison with his other, especially early, compositional production, in which Žebre followed radical trends of his time, his incidental music comes as a surprise. In the "Carniolian Comedians« he is bound by the text and historical background, whereas in Shakespeare's tragedy he is free to choose adequate means of expression. Why these means did not follow "new « tendencies in music can be explained by the fact that he ceased to compose soon after the War. Apart from that, music is only an ingredient of a theatrical work, and the composer is actually only a co-author who has to take into account his theatrical collaborators. 